\title{
Computer simulation in identification and elimination of waste in the production process
}

\author{
Agata Biniek $^{1^{*}}$, and Agnieszka Terelak-Tymczyna ${ }^{1}$ \\ ${ }^{1}$ West Pomeranian University of Technology, Faculty of Mechanical Engineering and Mechatronics, al. Piastów 19, 70-310 Szczecin, \\ Poland
}

\begin{abstract}
This paper lays the theoretical foundations for the characterisation the course of processes in production engineering by means of computer tools, with the focus on the essence and benefits resulting from the use the programmes in question. The main objective of this study is to employ a selected computer tool for modelling, analysing and simulating a selected product manufacturing process to identify areas in the process that require improvement. The work involved the Tecnomatix Plant Simulation programme, in which the existing production process was modelled. The created model was used to simulate the runtime of the production lot, identify bottlenecks and analyse production losses, such as: waiting, stocks, and unnecessary transport. The conducted analysis has produced an outcome in the form of methods for eliminating identified production losses and modifying the model. The simulations were subsequently carried out on a modified model, which allowed determining the level of improvement of the assumed indicators, e.g. order completion time, set-up time, waiting time, stocks. The selected tool served not only as a means to visualising the course of the manufacturing process but also enabled us to optimise and improve it. The article presents the possibilities of using simulation programmes to identify and eliminate waste in production processes. In addition, the conclusions show not only the results of the simulations but also the most important benefits resulting from the use of this type of tools in production engineering, in particular in lean production management.
\end{abstract}

\section{Introduction}

In today's age of technological progress, constantly growing needs and requirements of clients, enterprises should dynamically respond to market demands. It is connected with increasing the quality of products, diversifying the offer, while at the same time ensuring the minimisation of costs. Therefore, at each stage of the production process it should be possible to eliminate errors and losses and seek faster and cheaper solutions. Introducing changes by trial and error in the real process is too costly and time-consuming, which is why one of the solutions is the use of computer simulation. This type of activity is based on computer tools that enable modelling, simulation and analysis of the production process. The creation of a simulation model also enables checking several variants of the production system and selecting the most favourable one in terms of the adopted criteria. In the further part of the article, the Tecnomatix Plant Simulation programme was used to eliminate wastage in the modelled production process.

\section{The nature and benefits of computer simulation tools}

The essence of using these types of tools is to model and simulate existing production and logistics processes based on the assumed criteria, modelling processes, which are to be implemented in the near future or simulate changes in the production process at the time of introducing a new product. Furthermore, a detailed simulation model can be implemented in the evaluation of basic performance measures and analysis of system configurations [1, 2, 3]. Modelling is also used when other methods do not guarantee that the actual manufacturing system will reflect the assumptions of the theoretical (virtual) model [4]. It also allows engineers to check the validity of the assumptions made before their actual implementation, as well as to find weaknesses in the production process. Examining the course of the process using a simulation model allows $[1,2,3,5,6]$ :

-introducing changes without stopping the production process,

- cost minimisation,

- checking several variants of solutions, e.g. machine settings, selection of route and means of transport, number of operators, buffers,

-performing several analyses, simulating the process flow,

- finding losses,

- collecting and analysing data [7],

- easier and clearer presentation of data (graphic visualisation of the production process).

One of the tools used for computer simulation of manufacturing processes is the Tecnomatix Plant

${ }^{*}$ Corresponding author: agata.biniek@zut.edu.pl 
Simulation programme [8]. This software is designed for computer simulation and creation of digital models of processes of not only production but also logistic in order to check their performance and optimisation capabilities. The models built in this programme allow carrying out a series of experiments and analysing what will happen to the 'if' system, e.g. changes in the duration of activities - without disturbing the work of the actual production system. Tecnomatix Plant Simulation is equipped with advanced analytical tools allowing, inter alia, identifying bottlenecks, in addition to statistics and graphs, enabling the analysis of various production strategies. This programme has many important functions, including:

- object-oriented models with a hierarchical structure,

- open architecture with many standard interfaces,

- management of libraries and objects,

- genetic algorithms for optimisation,

- simulation and analysis of energy consumption,

- mapping and simulation of the value stream,

- automatic analysis of simulation results,

- building HTML-based reports. [9]

This piece of software enables, inter alia, analysis of the energy loss in the process, calculate the value added, simulate the course of the value stream and identify areas for improvement, e.g. waste time associated with the expectation of excessive stocks or under-production potential [10]. The tested model shows its features, advantages, disadvantages and limitations, so the great advantage is the possibility of any modification of the model and the introduction of various variants of improvements by the user. The suggested uses of the Tecnomatix Plant Simulation programme do not exhaust the potential of the referenced software [11].

The scientific literature in the field does include the Tecnomatix Plant simulation software to simulate production processes, e.g.: [12, 13, 14, 15] however these publications do not consider the energy used by the production line in the aspects of losses.

\section{Production process model}

The simulated process was executed for two types of products: a disc and a roller. The line consists of: four machining stations - saw, lathe, milling machine, grinder and quality control. Currently, the transport of materials and semi-finished products is carried out manually by operators. The diagram of the production line and the flow of materials and semi-finished products by successive machining stations for individual products are shown in Figure 1.

The production volume for the disc was set at 100 pieces, and for the roller at the level of 150 pieces. The machining times at individual positions for both products are presented in Table 1.

Table 1. Unit machining times at individual machining station for a disc and roller type.

\begin{tabular}{|l|l|l|}
\hline Workstation & disc & roller \\
\hline saw & $60[\mathrm{sec}]$ & $60[\mathrm{sec}]$ \\
\hline lathe & - & $195[\mathrm{sec}]$ \\
\hline milling machine & $160[\mathrm{sec}]$ & $140[\mathrm{sec}]$ \\
\hline grinder & $60[\mathrm{sec}]$ & $50[\mathrm{sec}]$ \\
\hline quality control & $60[\mathrm{sec}]$ & $60[\mathrm{sec}]$ \\
\hline
\end{tabular}

Set-up time for the saw station, lathe, milling machine and grinder is 10 minutes. The level of defective products was specified at $1 \%$.

The sizes of installed power for individual machines, presented in Table 2, were adopted in accordance with the information contained in publication [16].

Table 2. Characteristics of energy consumption by individual workstations.

\begin{tabular}{|c|c|c|c|c|c|}
\hline \multirow{2}{*}{$\begin{array}{c}\text { The name of } \\
\text { the } \\
\text { parameter }\end{array}$} & $\begin{array}{c}\text { Saw } \\
{[\mathrm{kWh}]}\end{array}$ & $\begin{array}{c}\text { Lathe } \\
{[\mathrm{kWh}]}\end{array}$ & $\begin{array}{c}\text { Milling } \\
\text { machine } \\
{[\mathrm{kWh}]}\end{array}$ & $\begin{array}{c}\text { Grinder } \\
{[\mathrm{kWh}]}\end{array}$ & $\begin{array}{c}\text { Quality } \\
\text { control } \\
{[\mathrm{kWh}]}\end{array}$ \\
\hline $\begin{array}{c}\text { The energy } \\
\text { consumed } \\
\text { during } \\
\text { operation of } \\
\text { the machine } \\
\text { without load }\end{array}$ & 1.2 & 4.9 & 6.24 & 4 & 0 \\
\hline $\begin{array}{c}\text { Energy } \\
\text { consumed } \\
\text { during Set- } \\
\text { up time }\end{array}$ & 1.275 & 5.2 & 6.6 & 4.25 & 0 \\
\hline $\begin{array}{c}\text { Energy } \\
\text { consumed } \\
\text { during the } \\
\text { processing } \\
\text { of the } \\
\text { product }\end{array}$ & 2.25 & 9.3 & 11.7 & 7.5 & 0 \\
\hline
\end{tabular}

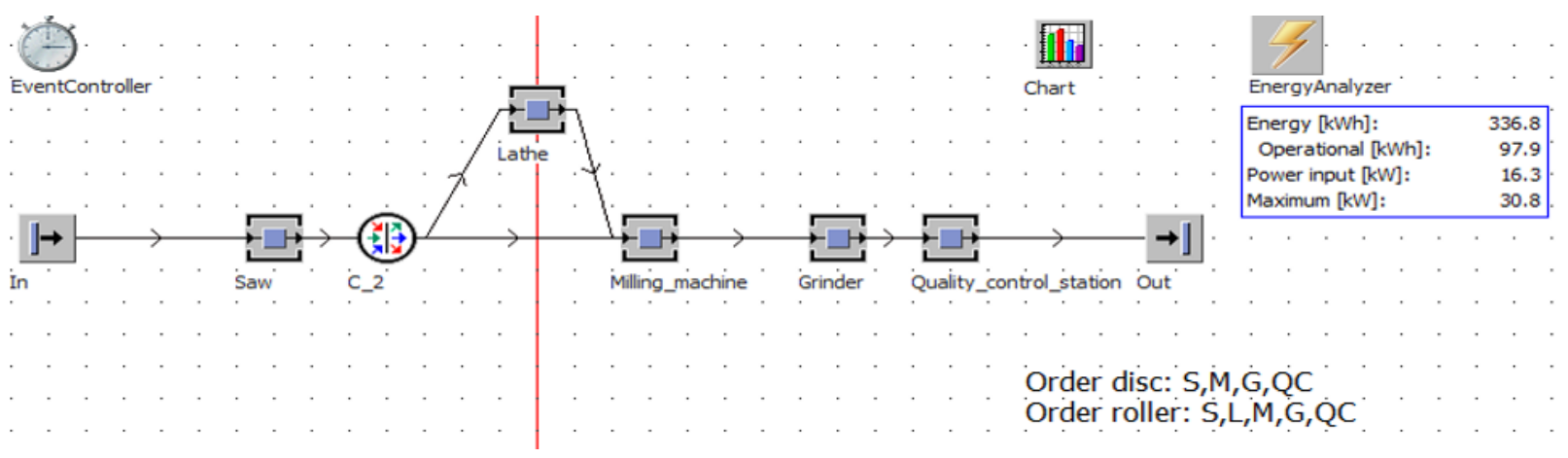

Fig. 1. Diagram of the production line and the course of materials and semi-finished products by processing stations. 


\section{Simulation results}

For such a designed model, the production process system simulated the course of materials and semiproducts through the production line [8]. The simulation results are presented in Tables $3 \div 4$ and in Figures $2 \div 3$.

Table 3. Parameters of electricity consumption divided into individual station.

Total Consumption and Portions of the Energy States

\begin{tabular}{|l|r|r|r|r|}
\hline \multicolumn{1}{|c|}{ Object } & $\begin{array}{c}\text { Total } \\
\text { Consum- } \\
\text { ption }\end{array}$ & $\begin{array}{c}\text { Work- } \\
\text { ing }\end{array}$ & Set-up & $\begin{array}{c}\text { Opera- } \\
\text { tional }\end{array}$ \\
\hline Saw & 21.12 & $44.38 \%$ & $3.02 \%$ & $52.60 \%$ \\
\hline Lathe & 97.94 & $63.31 \%$ & $1.77 \%$ & $34.92 \%$ \\
\hline Milling machine & 148.21 & $88.81 \%$ & $2.23 \%$ & $8.96 \%$ \\
\hline Grinder & 69.51 & $40.46 \%$ & $3.06 \%$ & $56.48 \%$ \\
\hline
\end{tabular}

Table 4. Parameters of use for individual station.

\begin{tabular}{|c|c|c|c|}
\hline \multicolumn{4}{|c|}{ Produced Part Types } \\
\hline Object & All Types & disc & roller \\
\hline Out & 250 & 100 & 150 \\
\hline \multicolumn{4}{|l|}{ Working Time } \\
\hline Station & Portion & Count & Sum \\
\hline Saw & $29.62 \%$ & 250 & $4: 10: 00.0000$ \\
\hline Lathe & $47.39 \%$ & 150 & $6: 40: 00.0000$ \\
\hline Milling machine & $79.98 \%$ & 250 & $11: 15: 00.0000$ \\
\hline Grinder & $26.66 \%$ & 250 & $3: 45: 00.0000$ \\
\hline Quality control & $29.62 \%$ & 250 & 4:10:00.0000 \\
\hline \multicolumn{4}{|l|}{ Set-up Time } \\
\hline Station & Portion & Count & Sum \\
\hline Saw & $3.55 \%$ & 3 & $30: 00.0000$ \\
\hline Lathe & $2.37 \%$ & 2 & 20:00.0000 \\
\hline Milling machine & $3.55 \%$ & 3 & $30: 00.0000$ \\
\hline Grinder & $3.55 \%$ & 3 & $30: 00.0000$ \\
\hline Quality control & $0.00 \%$ & 0 & 0.0000 \\
\hline \multicolumn{4}{|l|}{ Waiting Time } \\
\hline Station & Portion & Count & Sum \\
\hline Saw & $0.82 \%$ & 1 & $6: 55.7010$ \\
\hline Lathe & $44.61 \%$ & 5 & $6: 16: 29.9194$ \\
\hline Milling machine & $12.21 \%$ & 141 & 1:43:04.8791 \\
\hline Grinder & $69.75 \%$ & 248 & $9: 48: 40.0000$ \\
\hline Quality control & $70.22 \%$ & 248 & $9: 52: 38.2353$ \\
\hline \multicolumn{4}{|l|}{ Blocked Time } \\
\hline Station & Portion & Count & Sum \\
\hline Saw & $65.01 \%$ & 245 & 9:08:41.7863 \\
\hline Lathe & $5.03 \%$ & 11 & $42: 25.3195$ \\
\hline Milling machine & $2.93 \%$ & 3 & $24: 45.0000$ \\
\hline Grinder & $0.04 \%$ & 2 & 20.0000 \\
\hline Quality control & $0.00 \%$ & 0 & 0.0000 \\
\hline \multicolumn{4}{|l|}{ Failed Time } \\
\hline Station & Portion & Count & Sum \\
\hline Saw & $0.99 \%$ & 8 & $8: 22.5127$ \\
\hline Lathe & $0.60 \%$ & 5 & 5:04.7611 \\
\hline Milling machine & $1.32 \%$ & 11 & $11: 10.1209$ \\
\hline Grinder & $0.00 \%$ & 0 & 0.0000 \\
\hline Quality control & $0.16 \%$ & 2 & $1: 21.7647$ \\
\hline
\end{tabular}

Simulation time: 14:03:54.2990

\begin{tabular}{|c|c|c|c|c|c|c|}
\hline Name & $\begin{array}{c}\text { Mean Life } \\
\text { Time }\end{array}$ & $\begin{array}{c}\text { Thro- } \\
\text { ughput }\end{array}$ & TPH & $\begin{array}{c}\text { Product } \\
\text {-ion }\end{array}$ & $\begin{array}{c}\text { Stor- } \\
\text { age }\end{array}$ & $\begin{array}{c}\text { Value } \\
\text { added }\end{array}$ \\
\hline disc & $12: 34.0440$ & 100 & 7 & $\begin{array}{c}100.00 \\
\%\end{array}$ & $\begin{array}{c}0.00 \\
\%\end{array}$ & $\begin{array}{c}49.73 \\
\%\end{array}$ \\
\hline roller & $14: 11.2276$ & 150 & 11 & $\begin{array}{c}100.00 \\
\%\end{array}$ & $\begin{array}{c}0.00 \\
\%\end{array}$ & $\begin{array}{c}55.21 \\
\%\end{array}$ \\
\hline
\end{tabular}

Fig. 2. Simulation results for the production of disc and roller products.

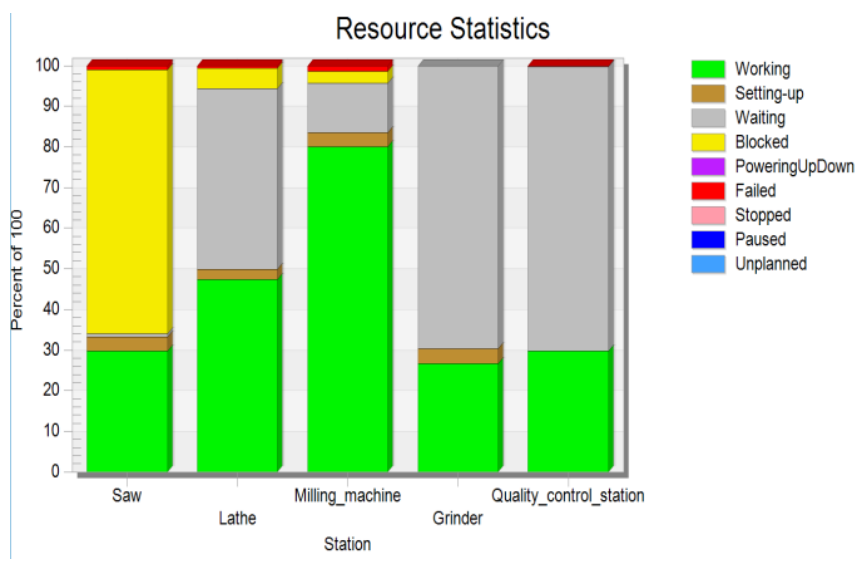

Fig. 3. The use of individual machines.

\subsection{Identification of waste}

The obtained analysis shows that the total simulation time is 14 hours 3 minutes and 54 seconds. The average machining time for the disc is 12 minutes 34 seconds and for the roller 14 minutes 11 seconds. TPH (Throughput per Hour) for a disc type product is 7 pieces, for a roller type product $11 \mathrm{pcs}$. It can be seen that the production line is not fully utilised, and the losses incurred increase production costs. Thanks to the possibilities that Plant Simulation brings, the analysis of the use of machines and electricity in the production process was made. In the analysed model, it was noticed that the biggest waste in the production process are losses related to the expectation. The biggest waste resulting from the waiting position is characterised by lathes, grinders and quality control. In addition to the waste related to the expectation, losses resulting from the consumption of resources in the form of electricity were analysed.

\subsection{Improvements to eliminate waste}

For the identified waste, possible solutions in the production process were identified, which were then introduced into the simulation model.

Table 5. Parameters obtained for individual products after changing the order of orders.

Simulation time: 14:04:00.0000

\begin{tabular}{|c|c|c|c|c|c|c|}
\hline Name & $\begin{array}{c}\text { Mean Life } \\
\text { Time }\end{array}$ & $\begin{array}{c}\text { Through } \\
\text { put }\end{array}$ & TPH & $\begin{array}{c}\text { Product } \\
\text {-ion }\end{array}$ & $\begin{array}{c}\text { Stor- } \\
\text { age }\end{array}$ & $\begin{array}{c}\text { Value } \\
\text { added }\end{array}$ \\
\hline disc & $12: 50$ & 100 & 7 & $100.00 \%$ & $\begin{array}{c}0.00 \\
\%\end{array}$ & $\begin{array}{c}48.69 \\
\%\end{array}$ \\
\hline roller & $13: 59$ & 150 & 11 & $100.00 \%$ & $\begin{array}{c}0.00 \\
\%\end{array}$ & $\begin{array}{c}55.97 \\
\%\end{array}$ \\
\hline
\end{tabular}


The first solution, due to the long waiting time of the lathe, was to change the order of jobs. However, this change did not lead to the reduction of the identified wastage nor did it cause any benefits. The results obtained are shown in Tables $5 \div 6$ and in Figure 4 .

Table 6. Electricity consumption divided into individual positions after changing the order of orders.

Total Consumption and Portions of the Energy States

\begin{tabular}{|l|r|r|r|r|}
\hline \multicolumn{1}{|c|}{ Object } & $\begin{array}{c}\text { Total } \\
\text { Consum- } \\
\text { ption }\end{array}$ & $\begin{array}{c}\text { Work- } \\
\text { ing }\end{array}$ & Set-up & \multicolumn{1}{|c|}{$\begin{array}{c}\text { Opera- } \\
\text { tional }\end{array}$} \\
\hline Saw & 21.12 & $44.38 \%$ & $3.02 \%$ & $52.60 \%$ \\
\hline $\begin{array}{l}\text { Lathe } \\
\text { Milling } \\
\text { machine }\end{array}$ & 97.94 & $63.30 \%$ & $1.77 \%$ & $34.93 \%$ \\
\hline Grinder & 148.22 & $88.80 \%$ & $2.23 \%$ & $8.97 \%$ \\
\hline
\end{tabular}

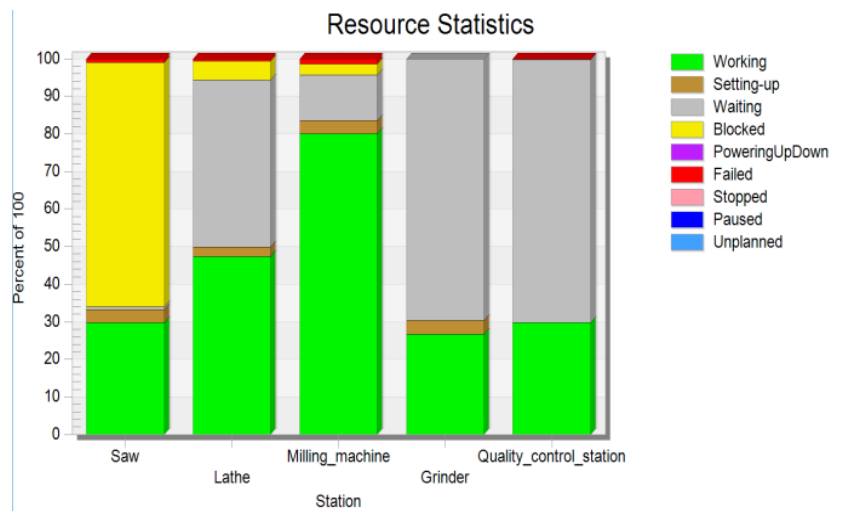

Fig. 4. The use of individual machines after changing the order of orders.

Another improvement due to the excessive load on the milling machine was the introduction of a buffer warehouse before the milling machine station. The storage capacity was set at 12 units. The simulation results for the model with the introduced improvement are presented in Figures $5 \div 6$ and in Tables $7 \div 8$.

The use of a buffer warehouse at the milling machine station produced the following benefits:

- execution time of production jobs decreased by 1 hour 15 minutes 54 seconds, i.e. $8.99 \%$;
- an increase in the number of products manufactured per hour by one item for individual products (TPH (Throughput per Hour) for a disc type product is recorded for 8 pieces, for a roller type product 12 pieces; - electricity consumption decreased by $20 \mathrm{kWh}(5.95 \%)$.

Table 7. Parameters obtained for individual products after entering a buffer warehouse.

Simulation time: 12:48:00.0000

\begin{tabular}{l|c|c|r|r|r|r|} 
Name & $\begin{array}{c}\text { Mean } \\
\text { Life } \\
\text { Time }\end{array}$ & $\begin{array}{c}\text { Thro- } \\
\text { ughp } \\
\text { ut }\end{array}$ & $\begin{array}{c}\text { TP } \\
\text { H }\end{array}$ & Production & Storage & $\begin{array}{c}\text { Value } \\
\text { added }\end{array}$ \\
\hline disc & $49: 48$ & 100 & 8 & $23.65 \%$ & $76.35 \%$ & $12.55 \%$ \\
\hline roller & $28: 49$ & 150 & 12 & $46.61 \%$ & $53.39 \%$ & $27.17 \%$ \\
\hline
\end{tabular}

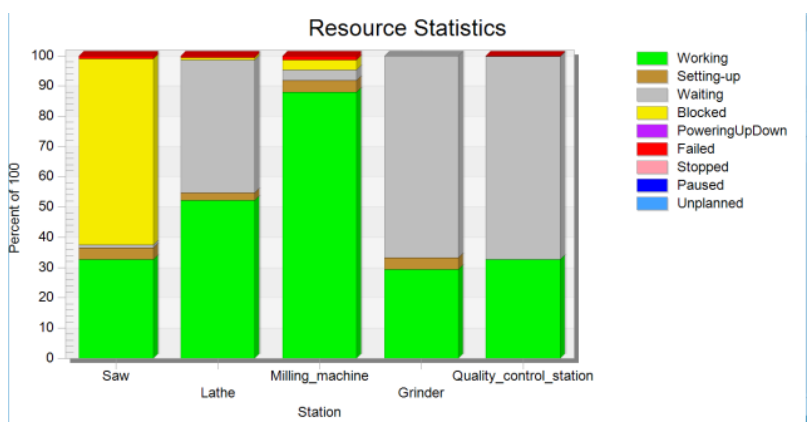

Fig. 6. The use of individual machines after entering the buffer warehouse.

Table 8. Electricity consumption divided into individual positions after the introduction of the buffer warehouse.

Total Consumption and Portions of the Energy States

\begin{tabular}{|l|r|r|r|r|}
\hline Object & $\begin{array}{r}\text { Total } \\
\text { Consum- } \\
\text { ption }\end{array}$ & Work-ing & Set-up & Operational \\
\hline Saw & 19.60 & $47.82 \%$ & $3.25 \%$ & $48.93 \%$ \\
\hline Lathe & 91.74 & $67.58 \%$ & $1.89 \%$ & $30.53 \%$ \\
\hline $\begin{array}{l}\text { Milling } \\
\text { machine }\end{array}$ & 140.32 & $93.81 \%$ & $2.35 \%$ & $3.84 \%$ \\
\hline Grinder & 64.45 & $43.64 \%$ & $3.30 \%$ & $53.06 \%$ \\
\hline
\end{tabular}

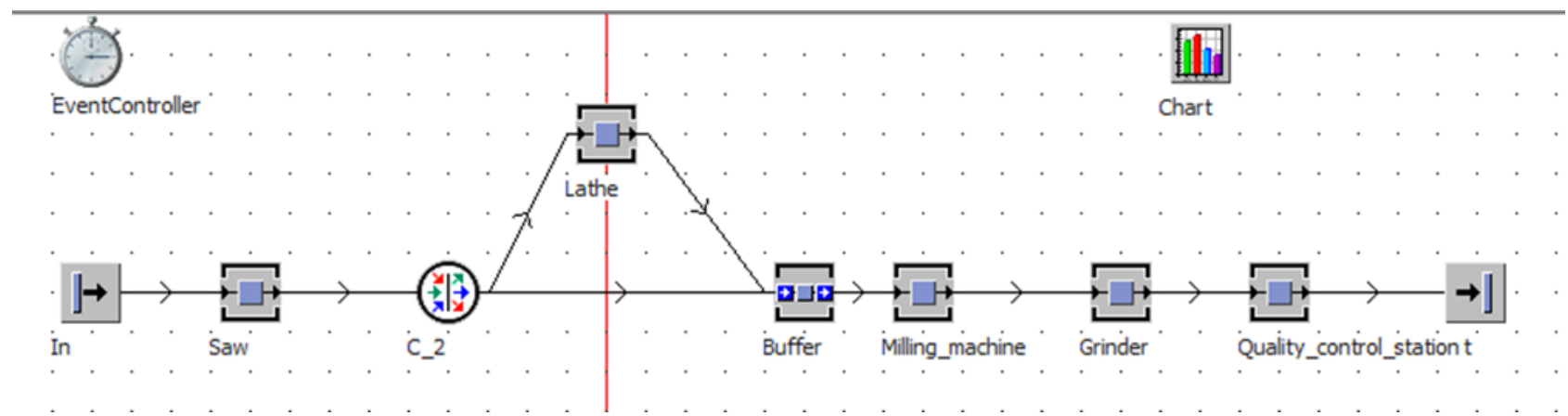

Fig. 5. Scheme of the production line after the introduction of the buffer warehouse and the course of materials and semi-finished products by the processing stations. 


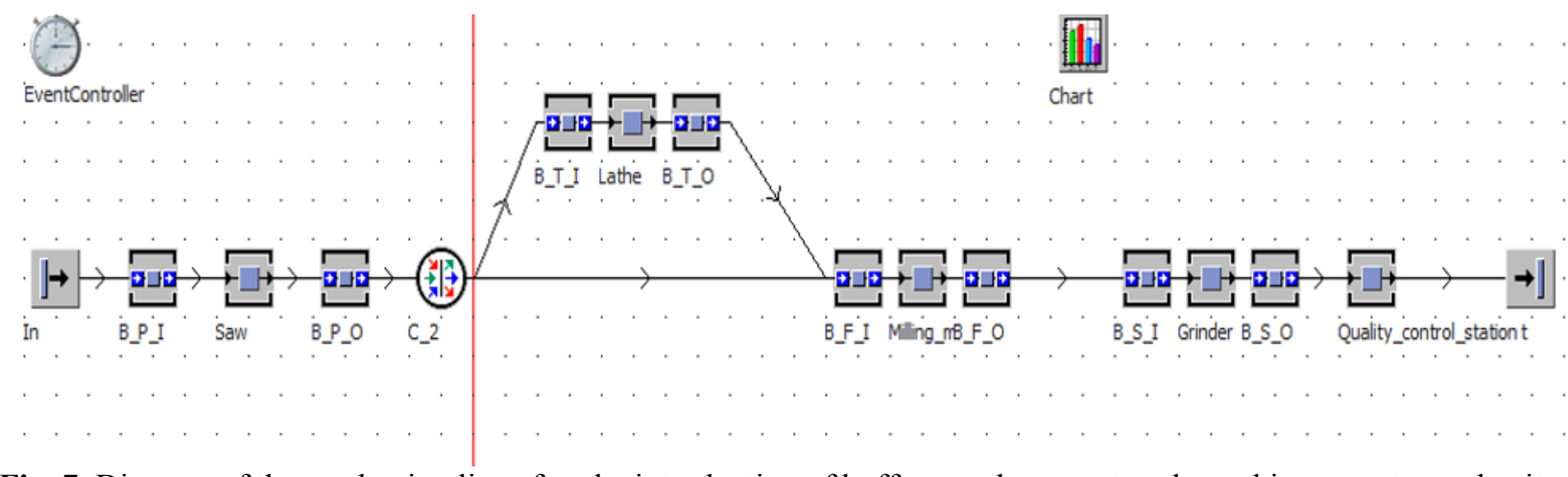

Fig. 7. Diagram of the production line after the introduction of buffer warehouses at each machine on entry and exit.

Due to the improved use of the milling machine following form the implementation of a buffer warehouse in the next simulation, the input and output buffers were used for each machine (Figure 7). The only position without a buffer warehouse was quality control. The storage capacity of the buffer warehouses was set at 5 units.

The results of the simulation for the model with the introduced improvement are presented in Tables $9 \div 10$ and in Figure 8.

Table 9. Parameters obtained for individual products after the introduction of buffer warehouses at production sites.

Simulation time: 6:08:00.0000

\begin{tabular}{|c|r|r|r|r|r|r|}
\hline Name & $\begin{array}{c}\text { Mean } \\
\text { Life Time }\end{array}$ & $\begin{array}{c}\text { Throug } \\
\text { hput }\end{array}$ & TPH & Production & Storage & $\begin{array}{c}\text { Value } \\
\text { added }\end{array}$ \\
\hline disc & $31: 49$ & 100 & 16 & $17.87 \%$ & $82.13 \%$ & $12.57 \%$ \\
\hline roller & $46: 42$ & 150 & 24 & $15.93 \%$ & $84.07 \%$ & $9.28 \%$ \\
\hline
\end{tabular}

Table 10. Electricity consumption by individual positions after the introduction of buffer warehouses at production sites.

Total Consumption and Portions of the Energy States

\begin{tabular}{|l|r|r|r|r|}
\hline Object & $\begin{array}{c}\text { Total } \\
\text { Consum- } \\
\text { ption }\end{array}$ & \multicolumn{1}{|c|}{$\begin{array}{c}\text { Work- } \\
\text { ing }\end{array}$} & Set-up & \multicolumn{1}{|c|}{$\begin{array}{c}\text { Opera- } \\
\text { tional }\end{array}$} \\
\hline Saw & 11.60 & $80.78 \%$ & $5.49 \%$ & $13.72 \%$ \\
\hline Lathe & 39.42 & $49.15 \%$ & $8.79 \%$ & $42.06 \%$ \\
\hline $\begin{array}{l}\text { Milling } \\
\text { machine }\end{array}$ & 56.66 & $68.83 \%$ & $11.65 \%$ & $19.52 \%$ \\
\hline Grinder & 37.78 & $74.44 \%$ & $5.62 \%$ & $19.94 \%$ \\
\hline
\end{tabular}

The use of buffer warehouses at the entry and exit of production sites allowed obtaining the following benefits:

- production time reduced to 6 hours 8 minutes, i.e. by $52.75 \%$ in relation to the previous improvement and by $57 \%$ in relation to the initial model (Table 9);

- the number of manufactured products increased within one hour to 16 items for the disc and 24 pieces for the roller, i.e. twice in relation to the second improvement and more than twice in relation to the initial model (Table 9);

- electricity consumption decreased by $171 \mathrm{kWh}$ $(45.88 \%)$ compared to the second improvement and by $191 \mathrm{kWh}(56.84 \%)$ in relation to the initial model (Table $10)$;
- increased use of machines and reduced waiting time (Figure 8).

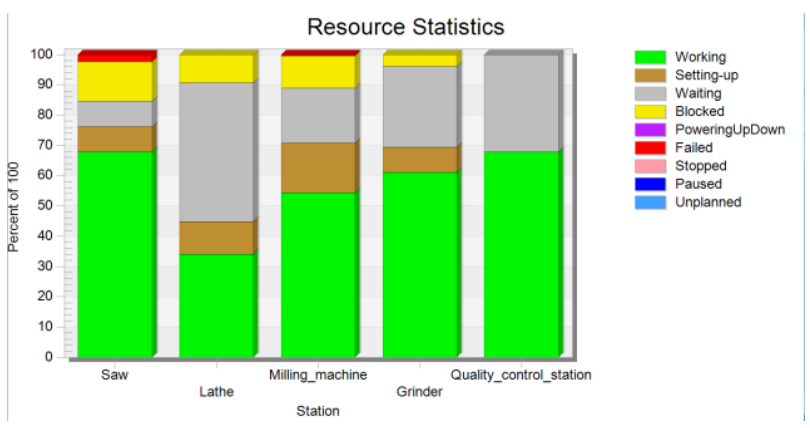

Fig. 8. The use of individual machines after the introduction of buffer warehouses at production sites.

\section{Conclusions}

The results of the simulation tests presented in the article indicate the possibilities of using simulation programmes to identify and eliminate waste in production processes.

In the presented model of the production process, through simulation we were able to identify areas of wastage in the process. This waste mainly concerned the waiting time for production sites. Relevant improvements were proposed to the model so as to solve the problem of excessive waiting for the goods before the machining station. Three solutions were proposed, and verified by means of the Plant Simulation software, w to check which of them will best contribute to the elimination of the identified wastage, without the need to change the real process. In the first solution, which was a change in the order of jobs, no simulation results were reported. Therefore, a buffer storage was proposed before the milling machine station. It resulted in shortening the time of execution of production orders, an increase in the number of manufactured products per hour and reduction of energy consumption. Due to the positive result of the simulation, an improved model introduced buffer warehouses for all machining stations. With this solution, not only has the production time been reduced or the energy consumption reduced but also the machine utilisation has been increased and the waiting time reduced.

As a result of the simulations, it was shown how the results of improvements in production processes can be easily checked and what benefits can be obtained from 
individual solutions. The simulation of just a few solutions has already enabled:

- shortening the order completion time by over $50 \%$,

- reduction of electricity consumption by more than $50 \%$,

- more than doubling the number of manufactured products per hour.

By using the software, one can easily identify wastefulness, perform a series of simulations and introduce simple improvements without incurring costs and implementing changes in the actual production process. The biggest benefit of using this type of tool is the ability to perform many simulations of process improvements and select the most favourable one in terms of the adopted criteria by the user.

\section{References}

1. F. A. Abdulmalek, J. Rajgopal, Int. J. of Production Economics, 107(1), 223-236 (2007)

2. J. Heilala, M. Paju, J. Montonen, M. Hentula, A. Heikkilä, Competitive and Sustainable Manufacturing, Products and Services, 01 (2010)

3. B. Chramcov, R. Bucki, S. Marusza, Adv. Intell. Syst. 210, 423-434 (2013)

4. O. Ciszak, Zeszyty Naukowe Politechniki Poznańskiej Budowa Maszyn I Zarządzanie, 06, 39-45 (2007)

5. S. J. Mason, R. R. Hill, L. Mönch, O. Rose, T. Jefferson, J. W. Fowler, Proceedings of the 2008 Winter Simulation Conference (IEEE, 2008)
6. M. S. Packianather, A. Davies, M. A. AlZarooni, S. Soman and J. White, 2016 World Automation Congress (WAC) (IEEE, 2016)

7. R. Zdanowicz, Pomiary Automatyka Robotyka, 1, 10-17 (2006)

8. S. Bangsow, Manufacturing Simulation with Plant Simulation and SimTalk: Usage and Programmong with Examples and Solutions (Springer-Verlag Berlin Heidelberg, 2010)

9. J. Patalas-Maliszewska, J. Jakubowski, S. Kłos, Inżynieria Produkcji Planowanie Modelowanie Symulacja, 09, 47-56 (2015)

10. K.K.Verma, V.Babele, IJO-Science Int. J. Online of Science, 04 (2014)

11. D. Mourtzis, M. Doukas, D. Bernidaki, Procedia CIRP, 25, 213-229 (2014)

12. V. V. Kokareva, A. N. Malyhin, V. G. Smelov, Applied Mechanics and Materials, 756, 604-609 (2015)

13. J. Siderska, Business, Management and Education, 14, 64-73 (2016)

14. W. Danilczuk, R. Cechowicz, A. Gola, Informatyczne systemy zarządzania, 05, 25-42 (2014)

15. M. Filo, J. Markovic, M. Kliment, P. Trebuna, American J. of Mechanical Engineering, 1(7), 165168 (2013)

16. A. Terelak-Tymczyna, A. Jardzioch, A. Biniek, Innowacje $w$ zarzadzaniu $i$ inżynierii produkcji, T.1 (Oficyna Wydawnicza PTZP, 2018) 